\title{
Analiza stanu naprężenie-odkształcenie w niklowych powłokach elektrolitycznych zawierających mikro- i nanocząsteczki twardej fazy
}

\section{Analysis of stress-strain in electrolytic nickel coatings containing micro- and nanoparticles hard phase}

\section{Streszczenie}

W artykule przedstawiono analizę stanu naprężeń i odkształceń w niklowych powłokach elektrolitycznych przeznaczonych do badań tribologicznych.

\section{Wstęp}

Powłoki węzłów tarcia wymagają koncentracji na maksymalnych naprężeniach w mikroobszarach warstwy wierzchniej, mogących spowodować przedwczesne zużycie części w węzłach tarcia wskutek zmęczenia materiału [1]. Formowanie się stanu naprężeniowego jest zależne zarówno od normalnego, jak i stycznego obciążenia. Naprężenia mogą mieć maksymalne wartości zarówno na powierzchni części, jak i na pewnej jej głębokości. Tak więc najważniejsze będzie wyznaczenie naprężeń rozciągających, które przyczyniają się do powstawania pęknięć podczas tarcia oraz zniszczenia materiału po upływie określonego czasu. Wpływ na taki stan mają naprężenia styczne nakładające się na naprężenia wewnętrzne powstałe po obróbce cieplnej [2].

Niklowe powłoki zostały naniesione metodą elektrolizy na próbki ze stali niestopowej, gdzie z elektrolitu niklowego osadzane były również cząstki SiC o frakcji $20 \mu \mathrm{m}$ oraz $50 \mathrm{~nm}$. Grubość powłok wynosiła $200 \div 250 \mu \mathrm{m}$.

Wskutek działania sił tarcia pojawiły się naprężenia w strefie zetknięcia dwóch powierzchni. Siły tarcia również znacznie zmieniają rozkład i wielkość naprężeń w tej strefie. W związku z tym badania wpływu fizykomechanicznych charakterystyk w powłokach

Dr inż. Edward Wajs - Politechnika Świętokrzyska, Kielce.

\section{Abstract}

The paper presents an analysis of stresses and strains in the electrolytic nickel coatings for tribological studies. oraz analiza rozkładu naprężeń w materiale w strefie styku istotnie wpływa na niezawodność i trwałość części obecnych w węzłach tarcia. Jako przykład mogą posłużyć powłoki Ni-B z dodatkową obróbką cieplną

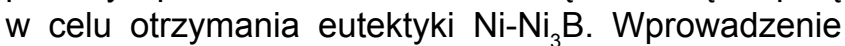
amorficznego boru do eutektyki powoduje tworzenie się wielowarstwowych gradientowych powłok na osnowie niklowej. Niezbędna będzie także analiza stanu naprężenie-odkształcenie w powłokach poddanych siłom tarcia oraz zależności stanu naprężeń i odkształceń od struktury materiału.

Należy podkreślić, że wyższymi właściwościami mechanicznymi cechują się powłoki, w których faza wzmacniająca ma budowę słupkową prostopadłą do powierzchni, niż powłoki z wtrąceniami o budowie kulistej.

Na rysunku 1 pokazano zależność modułu Younga od objętościowego udziału wtrąceń $\xi$. Krzywa 1 odpowiada charakterystykom mechanicznym $E_{1} / E_{m}$ dla materiału z wtrąceniami o budowie słupkowej, a krzywa 2 - dla materiału z wtrąceniami sferycznymi, gdzie $E_{1}$ odpowiada modułowi materiału kompozytowego $\left(\mathrm{Ni}+\mathrm{Ni}_{3} \mathrm{~B}\right)$, a $\mathrm{E}_{\mathrm{m}}-$ modułowi osnowy (Ni). Widać, że wraz ze zwiększeniem udziału objętościowego fazy wzmacniającej ze słupkową budową moduł sprężystości kompozytu wzrasta znacznie szybciej, niż w powłokach z wtrąceniami sferycznymi. Przekłada się to bezpośrednio na wyższe właściwości mechaniczne oraz zwiększoną odporność na zużycie.

Przy wyżarzaniu powłok Ni-B-SiC i Ni-B dzięki ukierunkowanej krystalizacji formowane są struktury 


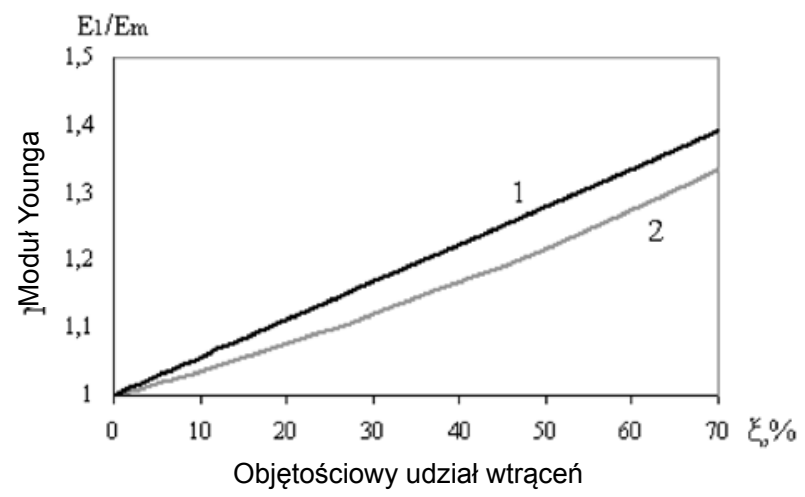

Rys. 1. Zależność modułu Younga od objętościowego udziału wtrąceń; 1 - wtrącenia z budową słupkową, 2 - wtrącenia $z$ budową kulistą [3]

Fig. 1. Dependence of Youngs modulus of the volume share of inclusions; 1 - inclusions of construction bars, 2 - construction of spherical inclusions

eutektyczne z budową dendrytyczno-słupkową. Dla danego materiału można więc określić model w stałym środowisku, jakie tworzą rozszerzone i zorientowane prostopadle do powierzchni tarcia, cylindryczne włókna z jednakowymi poprzecznymi przekrojami. Włókna rozmieszczone są w osnowie, której właściwości znacznie różnią się od właściwości włókien (rys. 2). Widoczne są także siły oddziaływania między włóknami, przy dużym udziale objętościowym. Prawdopodobnie włókna te rozłożone są w węzłach siatki tetragonalnej (rys. 3).

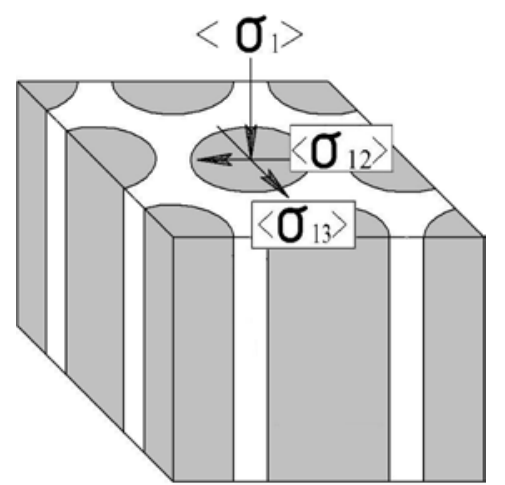

Rys. 2. Model kompozytowego materiału i schemat obciążenia Fig. 2. Model composite material and the load chart

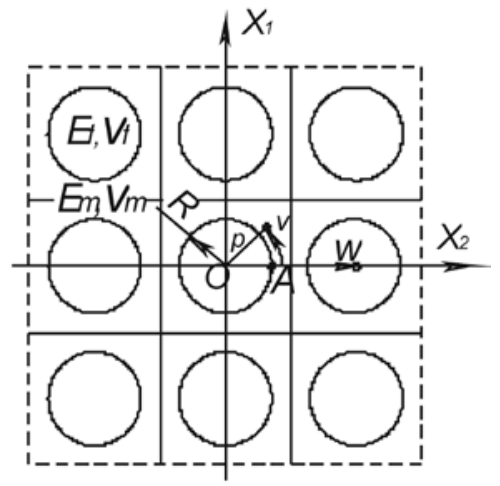

Rys. 3. Model strukturalny

Fig. 3. Structural model
$\mathrm{Na}$ materiał heterogeniczny działają naprężenia prostopadle do powierzchni, wywołujące naprężenia $\sigma_{1}$ i siły tarcia, wywołujące stan przemieszczenia wzdłużnego $\sigma_{12}, \sigma_{13}$ (rys. 2). W badanym modelu obszar w strefie kontaktu nie był brany pod uwagę, badane były tylko miejscowe pola naprężeń znajdujące się w niedużej odległości od powierzchni.

Dla danej strefy $z$ wtrąceniami lub w osnowie przedstawiono równania:

- równowagi dla objętości elementarnej:

$$
\begin{gathered}
\partial \sigma_{1} / \partial x_{1}+\partial \sigma_{1} / \partial x_{2}+\partial \sigma_{1} / \partial x_{3}=0 \\
\partial \sigma_{1} 2 / \partial x_{1}+\partial \sigma_{2} / \partial x_{2}+\partial \sigma_{23} / \partial x_{3}=0 \\
\partial \sigma_{1} 3 / \partial x_{1}+\partial \sigma_{23} / \partial x_{2}+\partial \sigma_{3} / \partial x_{3}=0
\end{gathered}
$$

- wzór na współczynnik sprężystości

$$
\begin{aligned}
& \varepsilon_{1}=\frac{1}{E} \sigma_{1}-\frac{v}{E}\left(\sigma_{2}-\sigma_{3}\right) ; \gamma_{12}=G \sigma_{12} \\
& \varepsilon_{2}=\frac{1}{E} \sigma_{1}-\frac{1}{E} \sigma_{2}-\frac{v}{E} \sigma_{3} ; \gamma_{13}=G \sigma_{13} \\
& \varepsilon_{3}=-\frac{v}{E}\left(\sigma_{1}+\sigma_{2}\right)+\frac{1}{E} \sigma_{3} ; \gamma_{23}=G \sigma_{23}
\end{aligned}
$$

- wzór Cauchy'ego

$$
\begin{array}{ll}
\varepsilon_{1}=\frac{\partial U}{\partial x_{1}} & \gamma_{12}=\frac{\partial U_{1}}{\partial x_{2}}+\frac{\partial U_{2}}{\partial x_{1}} \\
\varepsilon_{2}=\frac{\partial U}{\partial x_{2}} & \gamma_{13}=\frac{\partial U_{3}}{\partial x_{1}}+\frac{\partial U_{1}}{\partial x_{3}} \\
\varepsilon_{3}=\frac{\partial U}{\partial x_{1}} & \gamma_{23}=\frac{\partial U_{2}}{\partial x_{3}}+\frac{\partial U_{3}}{\partial x_{3}}
\end{array}
$$

gdzie: $\mathrm{E}$ - moduł Younga; G - moduł ścinania; $v$ - współczynnik Poissona; $\sigma_{i j}$ - naprężenia; $\varepsilon$ - deformacje normalne; $\gamma_{i j}$ - deformacje styczne; $U_{i}-$ przemieszczenia; $X_{i}-$ współrzędne.

W idealnych wzmocnionych liniowo materiałach struktura jest wyznaczana przez przemieszczanie włókien, co wpływa na charakter współpracy komponentów w polu naprężeń oraz na udział objętościowy napełniacza i materiału wiążącego.

\section{Przemieszczenia wzdłużne}

Badanie naprężeniowego stanu w środowisku wzmocnionym liniowo, zachodzącego podczas ścinania przy średnich naprężeniach $\sigma_{12}$ i $\sigma_{13}$, postawione zadanie prowadzi do wyznaczenia dwóch różnych funkcji $\phi_{\mathrm{m}}(\mathrm{z}) \mathrm{i} \phi_{\mathrm{f}}(\mathrm{z})$, odpowiednio $w$ osnowie i we wtrąceniach. Funkcje te są związane z przemieszczeniami wzdłużnymi $U_{1}$ i naprężeniami stycznymi $\sigma_{12}, \sigma_{13}$ przez następujące zależności:

$$
\begin{gathered}
\mathrm{U}_{1}=\phi(\mathrm{z})+\phi(\mathrm{z}) ; \sigma_{12}-\mathrm{i} \sigma_{13}=2 \mathrm{G} \varphi(\mathrm{z}) ; \\
\sigma_{13}=\mathrm{G}\left[\varphi(\mathrm{z}) \mathrm{e}^{\mathrm{i} v}+\varphi(\mathrm{z}) \mathrm{e}^{-\mathrm{iv}}\right]
\end{gathered}
$$


Strefa połączenia na granicy twarda faza-osnowa opisywany jest poniższą równością:

$$
\sigma^{+}{ }_{1 \mathrm{r}}(\tau)=\sigma_{1 \mathrm{r}}^{-}(\tau) ; \mathrm{U}_{1}^{+}(\tau)=\mathrm{U}_{1}^{-}(\tau)
$$

gdzie: znakami + i - oznaczone są obszary odpowiednio z prawej i lewej strony od granicy styku, a t oznacza współrzędna punktu na granicy.

Warunki połączenia sprowadzają się do zależności:

$$
\left(1+\mathrm{G}_{\mathrm{f}} / \mathrm{G}_{\mathrm{m}}\right) \phi_{\mathrm{f}}(\tau)+\left(1-\mathrm{G}_{\mathrm{f}} / \mathrm{G}_{\mathrm{m}}\right) \phi_{\mathrm{f}}(\tau)=2 \phi_{\mathrm{m}}(\tau)
$$

Do obliczeń konieczne są także wartości naprężeń $\sigma_{12}, \sigma_{13}$ lub kąty ścinania $\gamma_{12}, \gamma_{13}$, które dla tetragonalnej siatki opisywane są zależnościami:

$$
\gamma_{12}=\sigma_{12} / \mathrm{G}_{12} ; \gamma_{13}=\sigma_{13} / \mathrm{G}_{13}
$$

gdzie $\mathrm{G}_{12}$ - moduł wzdłużnego przemieszczenia materiału.

Zadania rozwiązano metodą spójnej regulacji. Opiera się ona na następujących zasadach: statyczne (lub długofalowe) pole zewnętrzne wzbudza wokół wtrącenia wewnętrzne pole, na co składają się rozproszone elementów (przy czym pierwszy komponent składa się ze stałej i oscylującej wzdłuż powierzchni twardych wtrąceń; następne komponenty pola, charakteryzujące się wzajemnym oddziaływaniem z wtrąceniami, mają jeszcze mniejsze rozmiary.

Wyrażenia dla rozkładu pola naprężeń ściskających $\sigma_{12}\left(\sigma_{13}=0\right) \mathrm{w}$ dowolnym punkcie osnowy:

$$
\begin{gathered}
\sigma_{12}=\frac{1+G_{f} / G_{m}}{1-\xi+(1+\xi) G_{f} / G_{m}}\left\{\left(1-S \frac{1}{\rho^{2}} \cos 2 v\right)+4 S \frac{\xi^{2}}{\pi^{2}}\left[3 \left(-\rho^{2} \cos v-\right.\right.\right. \\
\left.\left.+S \frac{1}{\rho^{4}} \cos 4 v\right)+7 \frac{\xi^{2}}{\pi^{2}}\left(-\rho^{6} \cos 6 v+S \frac{1}{\rho^{8}} \cos 4 v\right]\right\}\left|<\sigma_{12}\right\rangle \\
\sigma_{13}=\frac{1+G_{f} / G_{m}}{1-\xi+(1+\xi) G_{f} / G_{m}}\left\{-S \frac{1}{\rho^{2}} \sin 2 v+4 S \frac{\xi^{2}}{\pi^{2}}\left[3 \left(-\rho^{2} \sin 2 v\right.\right.\right. \\
\left.\left.\left.+S \frac{1}{\rho^{4}} \sin 4 v\right)+7 \frac{\xi^{2}}{\pi^{2}}\left(\rho^{6} \sin 6 v+S \frac{1}{\rho^{8}} \sin 8 v\right]\right\}<\sigma_{12}\right\rangle
\end{gathered}
$$

lub

$$
\begin{gathered}
\sigma_{1 r}=\frac{1+G_{f} / G_{m}}{1-\xi+(1+\xi) G_{f} / G_{m}}\left\{\left(1-S \frac{1}{\rho^{2}}\right) \cos 2 v+4 S \frac{\xi^{2}}{\pi^{2}}\left[3\left(-\rho^{2}+S \frac{1}{\rho^{4}}\right) \cos 3 v\right.\right. \\
\left.\left.+7 \frac{\xi^{2}}{\pi^{2}}\left(-\rho^{6}+S \frac{1}{\rho^{8}}\right) \cos 7 v\right]\right\}<\sigma_{12}>
\end{gathered}
$$

gdzie $S=\frac{1-G_{f} / G_{m}}{1+G_{f} / G_{m}} ; \xi-$ udział objętościowy napełniacza; $\mathrm{G}_{\mathrm{m}}$ i $\mathrm{G}_{\mathrm{f}}$ - moduły ścinania osnowy i napełniacza; $\rho$ i u - współrzędne punktu w osnowie. Dane wyrażenia uwzględniają efekty współdziałania pomiędzy włóknami i mają zastosowanie przy dostatecznie wysokim udziale objętościowym napełniacza.

Analiza wzoru (8) pokazuje, że koncentracja naprężeń ścinających jest maksymalna $w$ punkcie na granicy międzyfazowej o $\rho=1 ; v=0 ; \pi$, gdzie odległość między wtrąceniami jest minimalna (punkt $A$ na rys. 3). Maksymalny współczynnik koncentracji naprężeń ścinających wynosi:

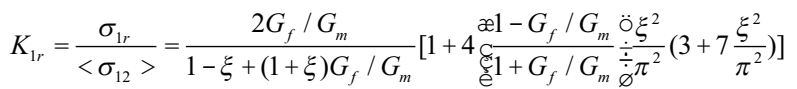

Wyrażenie to uwzględnia mechaniczne charakterystyki sładników, jak też ich udział objętościowy.

\section{Ściskanie wzdłużne}

Stan przy wzdłużnym rozciąganiu-ściskaniu ukazano w dwóch wariantach: stan rozciągania-ściskania bez uwzględnienia współdziałania pomiędzy komponentami przy nieznanej wielkości stałych naprężeń i założenia, że płaszczyzna $x_{1}=$ const nie wykrzywia się w procesie deformacji; 2) płaskiego deformacyjnego stanu w zadanych przemieszczeniach na granicach międzyfazowych przy braku odkształceń wzdłużnych. Przemieszczenia ustala się tak dla obydwu stanów na powierzchni kontaktu fazowego.

Analizując rozciąganie-ściskanie komponentów nie współdziałających, wyznacza się naprężenia w napełniaczu i osnowie odpowiednio

$$
\sigma_{1}=\mathrm{E}_{\mathrm{f}} / \mathrm{E}_{1} \sigma_{1}, \sigma_{1}=\mathrm{E}_{\mathrm{m}} / \mathrm{E}_{1} \sigma_{1}
$$

Podczas ściskania wzdłużnego materiału kompozytowego dzięki różnicy współczynników Poissona $v_{f}$ i $v_{m}$ wtrąceń i matrycy następuje płaski stan odształceń. Naprężenia w komponentach wyznacza się przez dwie niezależne funkcje $\varphi(z)$ oraz $\psi(z)$ :

$$
\begin{array}{r}
\sigma_{2}+\sigma_{3}=2[\varphi(z)+\varphi(z)] ; \sigma_{2}-\sigma_{3}+2 i \sigma_{23}=2\left[z \varphi^{\prime}(z)+\psi(z)\right] ; \\
\left(\sigma_{r}-i \sigma_{r v}\right)=\varphi(z)+\varphi(z)-2 e^{2 i v}\left[z \varphi^{\prime}(z)+\psi(z)\right]
\end{array}
$$

Analiza płaskiego stanu odkształceń opisanymi wyżej metodami, daje możliwość otrzymywania konkretnych wyrażeń dla pól naprężeń w osnowie [3]:

$$
\begin{aligned}
& \sigma_{2}=Q\left\{\left(\frac{1}{\rho^{2}} \cos 2 v-\xi\right)+9 \frac{\xi^{2}}{\pi^{2}}\left[T \frac{1}{\rho^{2}}\left(\cos 2 v-\frac{S-4 \rho^{2}}{\rho^{4}} \cos 6 v\right)+\rho^{2} \cos 2 v\right]\right\}<\sigma_{1}> \\
& \sigma_{3}=Q\left\{-\left(\frac{1}{\rho^{2}} \cos 2 v+\xi\right)+9 \frac{\xi^{2}}{\pi^{2}}\left[T \frac{1}{\rho^{2}}\left(\cos 2 v+\frac{S-4 \rho^{2}}{\rho^{4}} \cos 6 v\right)-\rho^{2} \cos 2 v\right]\right\}<\sigma_{1}> \\
& \left.\sigma_{23}=Q\left(\frac{1}{\rho^{2}} \sin 2 v-9 \frac{\xi^{2}}{\pi^{2}} \rho^{2} \sin 2 v+T \frac{5-4 \rho^{2}}{\rho^{4}} \sin 6 v\right)\right]<\sigma_{1}> \\
& \sigma_{r}=Q\left\{\left(\frac{1}{\rho^{2}}-\xi\right)+9\left[T \frac{1}{\rho^{4}}\left(6-5 \frac{1}{\rho^{2}}\right)+\rho^{2}\right] \cos 4 v \frac{\xi^{2}}{\pi^{2}}\right\}<\sigma_{1}>
\end{aligned}
$$

gdzie:

$Q=\frac{1}{E} \frac{4 G\left(v_{m}-v_{f}\right)}{2-\xi+\chi_{m} \xi+(1-\xi) G_{m} / G_{f}\left(\chi_{f}-1\right)} ; T=\frac{1-G_{m} / G_{f}}{\chi_{m}+G_{m} / G_{f}}$

Naprężenia w osnowie przy średnich wartościach ściskania podłużnego będą maksymalne w punktach granicy międzyfazowej, cechujących się największymi skupiskami wtrąceń. Wysoka wartość współczynnika koncentracji naprężeń wynosi:

$$
K r=\frac{\sigma_{r}}{<\sigma_{1}>}=Q\left\{1-\xi+3 \frac{\chi_{m}+1}{\chi_{m}+G_{m} / G_{f}}\left(3+10 \frac{\xi^{2}}{\pi^{2}}\right) \frac{\xi^{2}}{\pi^{2}}\right\}
$$




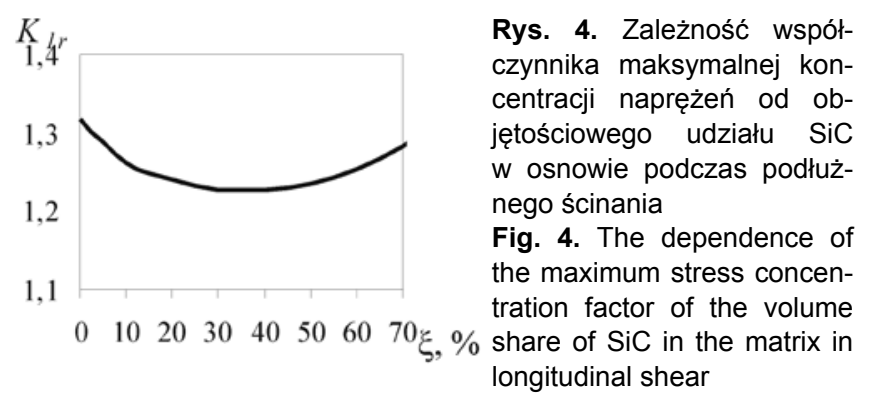

Tak więc, otrzymano analityczne wyrażenia dla miejscowych pól naprężeń $\sigma_{1}, \sigma_{2}, \sigma_{3}, \sigma_{23}, \sigma_{12}, \sigma_{13}$, które występują $w$ osnowie $w$ zależności od mechanicznych charakterystyk komponentów i struktury materiału kompozytowego.

Za pomocą przyjętej metodyki przeprowadzono obliczenia stanu naprężeń, jakie zachodzą w powłoce typu Ni-SiC skanowane wiązką lasera (rys. 4). Wyjściowymi danymi dla obliczeń były [3]: dla $\mathrm{Ni}$ osnowy - moduł sprężystości $\mathrm{E}_{\mathrm{m}}=1,86 \cdot 10^{5} \mathrm{MPa}$, moduł ścinania $\mathrm{G}_{\mathrm{m}}=0,72 \cdot 10^{5} \mathrm{MPa}$, współczynnik Poissona $v_{m}=0,3 ; \mathrm{Ni}_{3} \mathrm{~B}-\mathrm{E}_{\mathrm{f}}=2,9 \cdot 10^{5} \mathrm{MPa}, \mathrm{G}_{\mathrm{m}}=1,3 \cdot 10^{5} \mathrm{MPa}$, $v_{\mathrm{m}}=0,1$.

Wyznaczone za pomocą wzorów (12) naprężenia $\sigma_{2}, \sigma_{3}, \sigma_{23}$, które wynikają $z$ różnicy współczynników Poissona, cechują się małymi wartościami. Maksymalne koncentracje naprężeń ścinania $K_{1 r}$ będą znacznie większe niż ściskania $K_{r}$, zaś na stan naprężeń w powłoce większy wpływ będą miały naprężenia ścinania.
Koncentracja naprężeń ścinania znajduje się na granicy kontaktu składników w materiale kompozytowym w miejscach, gdzie odległości między wtrąceniami są minimalne. Początkowe obniżenie intensywności naprężeń stycznych związane jest ze zwiększeniem części nacisku przechodzącego na wtrącenia. Dalej (jeżeli wtrąceń jest ponad $40 \%$ obj.) zwiększenie intensywności naprężeń następuje z powodu wzajemnego oddziaływania z sąsiednim. Odległość między środkami wtrąceń wyznaczana jest za pomocą wzoru:

$$
\varpi=\sqrt{\pi / \xi}
$$

W materiałach, które zawierają $40 \%$ fazy wzmacniającej, $\omega=2,8 R$, gdzie $R$ - promień wtrącenia. Tak jest kiedy następuje zmniejszenie odległości między wtrąceniami w materiale kompozytowym i dochodzi do wzrostu naprężeń ścinających.

Przedstawione rezultaty świadczą o tym, że istnieje taki objętościowy udział wtrąceń $(30 \div 40 \%$ obj.), przy którym ustalono minimum intensywności miejscowych naprężeń stycznych w osnowie. Będzie to sprzyjać zwiększeniu odporności na zużycie takich materiałów. Tak więc, wychodząc $z$ idealnego wzorca, obliczono zależności koncentracji naprężeń $w$ kompozycie od korelacji właściwości mechanicznych i udziału objętościowego osnowy i wtrąceń. $Z$ analizy tych zależności wynika, że przy pracy w warunkach tarcia należy zwrócić szczególną uwagę na kompozyty zawierające $30 \div 40 \%$ obj. wysokomodułowych włókien.

\section{Wnioski}

Maksymalna koncentracja naprężeń ścinania zachodzi na granicy styku elementów wchodzących w skład materiału kompozytowego, gdzie odległość między wtrąceniami jest minimalna. W wyniku obliczenia ustalono, że kompozyty zawierające $30 \div 40$ obj.\% wysokomodułowych włókien mają minimalne lokalne naprężenia styczne w matrycy. Pokazano, że dla kompozytowych materiałów, w których właściwości mechaniczne komponentów i osnowy są zbliżone, koncentracja naprężeń zmniejsza się przy utrzymaniu charakteru jej zmiany odnośnie do zawartości fazy wzmacniającej.

Analiza stanu naprężenie-odkształcenie $\mathrm{w}$ wielowarstwowych powłokach pokazała, że największy wpływ na strukturalną budowę oraz warunki obciążenia mają naprężenia styczne $\mathrm{T}_{\mathrm{xy}}$ oraz normalne $\sigma_{\mathrm{x}}$.

Naprężenia normalne $\sigma_{y^{\prime}}$ parametry strukturalne i warunki tarcia (współczynnik tarcia) wpływają nieznacznie na odporność materiału.

\section{Literatura}

[1] Wajs E.: Wzmocnienie trących powierzchni poprzez elektroiskrowe nanoszenie powłok. Materiały konferencji - Państwowy Uniwersytet Lotniczy. Kijów, 1998, s. 14.

[2] Służałek G., Kubica M., Bara M.: Rozkład stanu naprężeń i odkształceń wybranych węzłów tarcia w badaniu warstw. Mechanik nr 1/2010.
[3] Kuzakow E.G.: Grafowa model uprugowo tela. Rasczot naprażeno-deformirowannowo sostojania.- Instytut Problem Procznosti, Kiev., 1985 s. 53.

[4] Nazarczuk T., Kornikowa W.: Metodyka chimiczeskowo analiza borsoderzaschich tugoplawich sojedinienij.- Instytut Problem Procznosti, Kiev. 1984 s. 50. 